\title{
EXCHANGE, CONFLICT AND COERCION: THE RITUAL DYNAMICS OF THE NOTTING HILL CARNIVAL PAST AND PRESENT ${ }^{1}$
}

\author{
Jennifer Edwards \\ Northeastern State University \\ J. David Knottnerus \\ Oklahoma State University
}

This study investigates patterns of relationships in the Notting Hill Carnival, an annual ritualized event. Specifically, we utilize two theoretical approaches in an integrative manner - elementary relations theory and structural ritualization theory - to better understand how the carnival has been strategically used in very different ways by various groups to accomplish their objectives. We suggest the Notting Hill Carnival is a collective ritual event that has played a crucial role in three quite different structured arrangements since its inception in London (and previously in Trinidad). In doing so, we bridge quite different theoretical approaches for analyzing social dynamics. Thus, our study contributes to the existing literature as we utilize these two perspectives to analyze how culture, ritual, and power have been intertwined in the production of the Notting Hill Carnival.

The Notting Hill Carnival is the largest street festival in Europe with approximately two million in attendance annually. The event, which was first held in London in 1965, takes place in the Notting Hill area in north Kensington on the August Bank Holiday. The carnival creates a festival atmosphere, characterized by masquerade, sound systems, dancing, and so forth (Melville 2002). Indeed, the Notting Hill Carnival may be described as celebratory. As Cohen (1983:102) states:

The loud beat, the music of the calypsonian, and the vigorous dancing -all accompanied by heavy drinking and smoking - go on for hours and induce an intense state of ecstasy and mirth among participants, who become so carried away by the spirit of the occasion that they lose track of the prescribed route and wander around the narrow streets until well into the night.

1 A version of this paper was presented at the annual meeting of the American Sociological Association, Las Vegas, 2011. 
While the Notting Hill Carnival emerged in London during the mid1960s the roots of this tradition date back to Trinidad in the 1830s. Prior to the abolishment of slavery, carnival was only celebrated by white elites. Hence, Blacks could only observe the event. After emancipation, however, berated slaves controlled carnival, using it as a way to celebrate their freedom. Be that as it may, opposition to the event was evident. "Official opposition to Carnival has been a consistent feature of its history both in Trinidad and in Britain" (Jackson 1987:215).

\section{REVIEW OF THE LITERATURE}

Research regarding the Notting Hill Carnival focuses on collective memory, the social construction of reality, and periods of transformation. In regard to collective memory, some research indicates that Notting Hill Carnival participants converge and take part in the annual festival due to similarities or shared qualities involving ethnicity. This sense of ethnic similarity has survived because of collective memory. This holds especially true today as the carnival is managed by members of Black British culture who base the festival largely on group memory. Connerton (1989) observed that images of the past legitimate present action. Thus, collective memory and knowledge of the past play a major role in helping to perpetuate this ritualized celebration.

The social construction of reality is another widely accepted approach in sociology and this concept relates directly to the Notting Hill Carnival. Cohen (1982) has explored the dramatic processes underlying rituals, ceremonies, and other symbolic activities in the social life of the carnival, focusing on how the relationships between the people become associated with a body of values and norms and a set of beliefs and practices. Carnival participants often make political statements by ridiculing the ruling class in an attempt to modify power relationships.

Finally, the Notting Hill Carnival reflects periods of transformation. The mobilization of West Indians in the Notting Hill community led to the development of carnival as an exclusive gathering. Today, the Notting Hill Carnival is a multicultural event. However, while the event has changed over time, it continues to express political and ideological concerns that involve conflicting groups and views, especially those involving race and racism (see Jackson 1987).

Our study examines the Notting Hill Carnival in a different manner. While informed by the valuable insights and contributions of the three aforementioned approaches often used to study this event the present investigation focuses on how the ritual of carnival is at the center of very different types of social relationships among various kinds of groups. Hence, we emphasize how cultural phenomena such as collective rituals are shaped by and in turn influence the structural relationships that form 
among groups and the various qualities that define those relationships such as differences in power, economic gain or loss, and social inequality.

From our perspective the Notting Hill Carnival may best be thought of as an annual ritualized event. It is a social ritual that attracts large numbers of people and provides symbolic and emotional gratification to its participants. It has also been a ritual that has changed through the years and has impacted both individuals and the wider community in many different ways. To better understand and study these developments we draw upon two theoretical/research programs. The first one structural ritualization theory - provides a theoretical framework for conceptualizing the Notting Hill Carnival as a social ritual and understanding some of the ritual dynamics which define this social practice. The following discussion provides an introduction to structural ritualization theory and the concepts of strategic ritualization and special collective ritual events.

\section{STRUCTURAL RITUALIZATION THEORY}

Structural ritualization theory (Knottnerus 1997, 2005, 2009, 2010. 2011) focuses on the role rituals play in social life, especially in the formation, reproduction, and alteration of social structures. Central to the theory is the concept of ritualized symbolic practices (RSPs) which refer to action repertoires that are schema-driven. RSPs involve common forms of social behavior in which people engage in standardized and repetitious actions when interacting with others. Occurring in either sacred or secular contexts, RSPs are based on cognitive frameworks and involve regularly engaged in actions that possess meaning and express symbolic themes. ${ }^{2}$

\section{Strategic Ritualization}

One useful concept within structural ritualization theory is "strategic ritualization." This idea emphasizes how social rituals can play a central role in social life and sometimes are carried out in a deliberate and purposive manner. Thus, "agents can strategically engage in ritualized practices and actively foster the reproduction or transformation of social structures for various purposes including self-aggrandizement"

2 Research employing structural ritualization theory includes Bhandari, Okada, and Knottnerus 2011; Guan and Knottnerus, 1999, 2006; Lin, Guan and Knottnerus 2011; Knottnerus 1999, 2002; Knottnerus and Van de Poel-Knottnerus 1999; Van de PoelKnottnerus and Knottnerus 2002; Knottnerus and Berry 2002; Knottnerus, Ulsperger, Cummins and Osteen 2006; Minton and Knottnerus, 2008; Mitra and Knottnerus, 2004, 2008; Sell, Knottnerus, Ellison and Mundt, 2000; Sarabia and Knottnerus 2009; Thornburg, Knottnerus and Webb 2007, 2008; Ulsperger and Knottnerus, 2007, 2008, 2009a, 2009b, 2011; Varner and Knottnerus 2002, 2010. 
(Knottnerus 1997:275). Stated another way, people may utilize or manipulate a system of ritualized practices in order to create certain outcomes. Four types of strategic ritualization have been identified. They include: ritual legitimators, ritual entrepreneurs, ritual sponsors, and ritual enforcers (for a discussion of these concepts see Knottnerus, Van Delinder, and Edwards 2011).

Another concept used to examine strategic ritualization is "program of ritualized symbolic practices" which is defined as "a collection of RSPs strategically used by a group or individuals such as group leaders to achieve certain objectives" (Knottnerus, Van Delinder, and Edwards 2011:80). This concept emphasizes how programs of ritual practices may differ in type, frequency, and so forth. As such, these ritual programs may vary in their complexity. Research has begun to examine the various ways groups have constructed and strategically used ritual programs.

While several studies have been conducted using these ideas, structural ritualization theory does not focus on the nature of relationships that occur between groups and how groups may strategically use rituals (and programs of ritual practices) to create certain outcomes which contribute to the formation and perpetuation of these structured relations. Of particular interest is how special collective ritual events such as the Notting Hill Carnival may be strategically used by people, e.g., the carnival's organizers, participants, the wider community, or elites and agents of social control in the wider community. To more fully address this issue we draw upon another approach: elementary relations theory. However, let us first define what we mean by special collective ritual events.

\section{Special Collective Ritual Events}

One recent development in structural ritualization theory focuses on the analysis of special collective ritual events and their effect on actors (Knottnerus 2010). Several features distinguish this type of occurrence. First, this type of event is clearly separated from everyday behaviors. That is, it represents a distinctive social activity. Second, these events take place in a regularized manner. As Knottnerus (2010:41) states, special collective ritual events are "usually engaged in on a periodic basis whether that involves, for instance, a set time schedule or their staging being connected to other social developments (e.g., a military celebration marking the completion of basic training or a pep rally preceding a ball game)."

In addition to occurring in a regularized manner, special collective ritual events involve stylized activities. These include one or more activities or practices in which people engage "in behaviors that are quite recognizable due to their definitive form or style (e.g., marching, danc- 
ing, singing, praying, speech-making, making vows, or oaths)" (Knottnerus 2010:41). Finally, special collective ritual events involve multiple actors. While it is generally believed that these events are engaged in collectively, the number of people involved can vary. In addition, the possibility exists that an event may be engaged in by a single individual. It is possible that a person who is totally isolated from others (e.g., a lone researcher in an arctic station) may celebrate the event and perform some version the ritual in a modified form.

Because the Notting Hill Carnival exhibits all of these of characteristics it may be considered a special collective ritual event. Moreover a preliminary review of evidence indicates that this collective ritual event has over time involved various patterns of relationships between different groups. To better analyze this issue we draw upon another approach which has given formal attention to some of the major types of structural relationships that develop among individuals and collectivities: elementary relations theory.

\section{ELEMENTARY RELATIONS THEORY}

Elementary relations theory is based on the knowledge that social relations are found in every society and these relations can be represented by a series of typologies presented by Willer. As Willer (1999:23: see also Willer and Anderson 1981; Willer and Markosvky 1993) states:

At the core of Elementary Theory is a 'modeling procedure' that is used to build models for properties inside the actor, like preferences and beliefs, and for properties outside the actor, like social relations and social structures. These are theoretic models for actors in relations in structures, and they begin with simple elements, 'sanctions' that are connected to generate preferences, beliefs, and relations.

Willer (1999:25) also suggests that "sanctions are paired in social relations because each actor's decision affects the other's preference state." We utilize elementary theory to determine whether and how the types of relationships, identified in elementary theory, occur in the Notting Hill Carnival.

Three key types of relations are identified by Willer (1999). They include: a) coercion, b) conflict, and c) exchange. Coercion represents a relation in which "one actor has a negative sanction and the other has a positive sanction. The actor with the negative is the coercer and the actor with the positive is the coercee" (Willer 1999:27). Moreover, the coercer may threaten coercees with a negative transmission in order to ensure a 
positive response from the coercee. Thus, if the coercer's threat is successful, and the coercee sends the positive, the coercer will not send the negative. Yet, if the coercee fails to respond with the positive, the coercer will administer the negative.

The conflict relation also involves agreement and confrontation but takes a different form. As Willer (1999:27) argues:

In conflict, because the two transactions are negative, neither actor benefits when the sanction of the other is transmitted. Therefore, agreements are concerned with the conditions under which no sanctions flow. When an agreement is not attained, the relationship is in confrontation and both actors transmit their negatives.

Exchange relationships develop when both actors benefit. Stated somewhat differently, while agreement and confrontation are both important to exchange relationships, both actors benefit when sanctions are sent and an agreement is reached in regard to the number of sanctions sent by each actor (Willer 1999).

In the present study we analyze whether and to what extent the Notting Hill Carnival is involved in coercive, conflictual, and exchange relations. Further, we identify and analyze four time periods where distinct changes in the nature of these structured relationships have occurred. They are: a) 1800s Trinidad; b) the Notting Hill Carnival from 19651970; c) the Notting Hill Carnival from 1971-1989; and d) the Notting Hill Carnival from 1990-present. The development of these categories initially emerged out of the preliminary analysis of various written materials related to the Notting Hill Carnival and were subsequently confirmed with the much more extensive formal analysis employing concepts from elementary theory (and structural ritualization theory).

We include the beginning period of the Trinidad carnival (1800s) since this festival provides the roots for the Notting Hill Carnival. However, for the purposes of the current study it is not necessary to analyze the entire history of carnival in Trinidad. While the Trinidad carnival is important as it represents the foundation of the London carnival our primary focus for this study is the Notting Hill Carnival. In this regard it is worth noting that the participants in the current Trinidad carnival continue to protest against similar poor economic and social conditions as participants did in the 1800s (Bereton 1985). Moreover, Jackson (1987) points out that the songs sung in Trinidad during the 1830s exhibit a number of similarities to the songs sung today. Participants during the 1830 s - 1890s sang songs that were critical of their former masters. Jackson (1987) contends that today the songs remain critical because people continue to protest against inadequate economic and social condi- 
tions. As a result, we do not believe an analysis of the entire history of the carnival is necessary for the current investigation.

In sum, we suggest that structural ritualization theory provides the framework for understanding the Notting Hill Carnival as a ritualized symbolic practice. Further, the concept of strategic ritualization demonstrates the various ways ritual behavior may be conducted in a purposive manner, i.e., how rituals such as carnival may be used to produce certain outcomes. Additionally, we contend that the Notting Hill Carnival represents a special collective ritual event as it possesses each characteristic of such events. Finally, we argue that this annual ritual event involves various patterns of relationships which we focus on here to determine the extent to which these patterns exist in the Notting Hill Carnival.

Our analysis is, therefore, grounded in an integration of elementary relations theory and structural ritualization theory. Key concepts from both perspectives are linked to explain in a more comprehensive manner the social dynamics surrounding carnival. Indeed, such a bridging or integrative exercise enhances our ability to better understand the significance of this social event over an extended period of time.

\section{METHODS AND ANALYSIS OF DATA}

To investigate the social relationships involving the ritualized practice of carnival, we employ content analysis. Numerous written materials were analyzed including academic sources (i.e., books, articles, and so forth), newspaper articles, photographs, archival documents, and oral histories.

A large amount of data was collected at the Kensington \& Chelsea Community History Group (i.e., HISTORYtalk) in London by the first author. Certain materials such as oral history interviews as well as some archival material were obtained at the main location of the history group. The remaining materials were collected at the Kensington Central Library. These materials are the property of the Kensington \& Chelsea Community History Group, but are housed at the library. The use of content analysis allowed us to collect data in an unobtrusive manner. Further, this method allowed us to obtain detailed evidence (including historical information) that we would be unable to collect through observations alone.

Data were analyzed according to the types of social relationships outlined in elementary theory (i.e., coercion, conflict, and exchange). Specifically, we identified both manifest and latent content as they relate to social relationships and the special collective ritual event of the Notting Hill Carnival. That is, we identified content which revealed obvious associations to the typologies outlined in elementary theory. In addition, we identified latent content or the underlying meaning contained in the 
documents that provided evidence either supporting or refuting the existence of a particular type of social relationship in the Notting Hill Carnival (see Babbie 2004).

The following discussion provides a presentation and discussion of the findings, focusing on each time period selected for analysis. Data from archival and other relevant sources are presented and discussed.

\section{FINDINGS}

\section{TIME PERIOD \# 1}

The social relationship of coercion is clearly visible in Trinidad prior to the 1830s. The data reveal that prior to the abolition of slavery in 1834 carnival was only celebrated by white elites; that is, the black population was only permitted to observe the event (Jackson 1987). Thus, as reported by carnival scholars:

In Trinidad, during the days of slavery, Black people (slaves) were forbidden to play musical instruments and wear costumes, apart from when the traditional imported European carnival took place, six weeks before Easter. On those occasions their participation was limited to providing entertainment for their masters (www.thecarnival.tv/info).

Although freed slaves were permitted to engage in celebrations following emancipation, the social relationship between the black and white populations was dominated by conflict. Hence, carnival represented a political event which highlighted numerous social problems such as racism as well as political and social inequities and tensions (Jackson 1987). Carnival became a place where freed slaves could highlight some of these issues.

Consequently, slaves would dress like their masters or make masks to resemble their masters, distorting images and features if they regarded their masters as particularly evil or ridiculous. These celebrations of freedom provided the only opportunity for Black people to express their feelings about their [former] slave masters and they quickly developed the art of costume making, creating fantastic costumes which satirized their situation as Africans, transported to the Caribbean as slaves (www.thecarnival.tv/info).

So too, participants protested against poor economic conditions (Bereton 1985). As a result, official opposition to Carnival by the government and other elites grew. Even in 1833 a municipal ordinance was 
passed banning the use of drums in public areas. As Jackson (1987:215) states "official opposition to carnival has been a consistent feature of its history both in Trinidad and Britain." Furthermore, additional sanctions were applied in the following years. For instance, in 1846 the governor of Trinidad forbade the wearing of masks in the street. Then, in 1858 masquerade was banned. Finally, in 1895 cross-dressing was prohibited (Jackson 1987).

In discussing the efforts by those in power to suppress carnival, Gutzmore (1993:210) provides a succinct and accurate summary:

The Trinidad carnival which is part of the history of the Notting Hill Carnival, started off as a mode of cultural expression by, initially, white people, in Trinidad. Extraordinary efforts went into trying to suppress the carnival in Trinidad in the last and present century. . from the 1830 s in fact, they brought in legislation cutting out carnival jollification on the Sunday when it was supposed to take place.

\section{TIME PERIOD \#2}

The initial period of the Notting Hill Carnival in London involved a type of social exchange. Hence, "it was at this stage that the carnival was first held on the streets in the form of a multicultural English carnival procession" (www.listentotheworld.net).

Carnival, a tradition from Trinidad, was originally designed to bring people together, a chance for people to meet with each other (Oral History Interview 2001). Thus, during the early years the Notting Hill Carnival was not a contentious event. As Gutzmore (1993:215) observed:

The Notting Hill Carnival started within the framework of culture -it was a cultural event. What it emphatically did not start as was potentially challenging culture. It never looked, until recent years, as a piece of expression by the black masses that could challenge in significant ways the state or its police. And so, for the first several years of its life, the Notting Hill Carnival was left alone.

Gutzmore then goes on to state that:

When the steel band came to the Notting Hill Festival in 1964, nearly every West Indian as well as local white people, came onto the streets in celebration, song and dance enthused by the infectious renditions of popular songs or pan. For the first time Black people could express themselves freely on the streets of Notting Hill in appreciation of the music and togetherness and remi- 
niscing of the carnivals back home (www.thecarnival.tv/ info).

In addition, he contends that the reason the Notting Hill Carnival was left alone during these early years is that it was controlled by the whites. Providing further clarification of this point Hulls (1997:8) argues:

Carnival has been celebrated by the ruling class as well as by the common people. The ruling classes have utilized it as a means to maintain the status quo as a safety valve, granting liberty and dissipation to the masses for a few days per year, but no longer.

Hence, carnival provided an emotional outlet for working-class people; that is, it gave them the ability to protest (to a certain degree) against such conditions as poor housing and other problematic social conditions (Jackson 1987). As Jackson (1987:216) observes:

During the 1960s the festival enabled the working class residents of the area to mobilize against bad housing conditions, opposing urban renewal and protesting about the construction of the M40 flyover. After the arrival of a large Afro-Caribbean ('West Indian') population in the 1960s, Carnival began to take on its contemporary form and range of associations.

In essence, through such collective actions and the overall celebratory quality of the festival, participants could give voice to their sentiments and vent their feelings. In return (from the perspective of the dominant groups concerned with maintaining order in the community such as political elites, police, lawmakers, and so on) social and political stability was preserved. Stated more formally this give and take between different groups in the community involved a social exchange in which both parties benefited albeit in different ways.

\section{TIME PERIOD \#3}

From 1971 to 1989 , the social climate involving the Notting Hill Carnival was one of conflict (more precisely the transition to the third period occurred between approximately 1970 and 1975). During this time, carnival began to experience problems. Indeed, Gutzmore (1993: 208) argues "the Notting Hill Carnival is perhaps the most spectacular of those cultural events that actually led to violent confrontation between the black communities and the state." So too Carver (2000:36) states that the problems began after 1973 with the local people: 
The context of the carnival, mobilizing the local working class, could not help but give it a political context. By the 'seventies,' the carnival had become an almost entirely West Indian event. . .Its identity became entwined with the situation of West Indians in Britain, who saw themselves as the victims of a white authoritarian culture.

The result was "problems with police, local authorities, many people not wanting carnival, others rebelling" (Oral History Interview 2001). As Gutzmore (1993:216) suggests:

Problems began when carnival was viewed as mass culture. But particularly Capital Radio was used on the scene of the 1975 carnival. . .Naturally five hundred thousand people, or thereabouts, attended the carnival. Once that happened, five hundred thousand people they weren't all blacks - even a quarter million black people - in those streets, the police were terrified out of their tiny little minds, they really were. Once that happened, the carnival entered the domain of threatening culture, because it was then mass culture, active mass culture and it had therefore to be suppressed, or controlled.

The same author (1993:214) also notes how such tendencies were already in place before this time period:

I've already mentioned what the police did in 1958; but throughout the 1960s, and early 1970s, blacks were systematically brutalized in Shebeens and house parties and so on; the Mangrove restaurant was constantly harassed up until the period of the demonstration which led to those arrests and the trial that is now famous as the Mangrove Nine Trial. . .So that, although I say there were no major moves by the state at suppressing major elements of culture, there were moves against all the small manifestations of black culture, the culture of the black masses. . .It should be noted that the British state also attacked and destabilized the political organizations of the black masses in this period.

During this third time period, the carnival became a contentious event. According to the Notting Hill Carnival Organizational Review (1988:1) several issues played a role in creating the hostile environment.

The growth of carnival has made it a contentious event. As with any very large gathering of people there are con- 
siderable problems of noise, congestion, litter and damage. Safety and security are major concerns - there have been no fires but street crime has been a running sore. At the same time, for the majority of participants, carnival is an enlivening and happy time, the result of months of dedicated industry in preparing the costumes and music. Because of the problems there has been antagonism or ambivalence towards the event.

Further, the report suggests that another problem concerning public safety relates to how this issue is handled. Thus, if handled improperly the conflict may escalate, causing one or both sides to engage in negative actions toward one another. On the other hand if they adopt a "hands off" approach in an attempt to avoid provocation, they risk not being able to adequately control crime (Notting Hill Carnival Organizational Review 1988). Stated somewhat differently, the police face conflicting demands.

In regard to this time period, 1975 appears to represent a major turning point in the Notting Hill Carnival. As Gutzmore (1993:219) states:

But there was a long battle following the 1975 carnival, for the preservation of carnival itself, and for the retention of it on the street. That battle involved some very weak leadership on the part of the carnival committee, while on the other side were some groups that were already discredited as racist. . The state proper as represented by the police was a different matter altogether. They also had the major disadvantage that the local council had, namely that they had no legal basis on which to seek a ban by the home secretary. So all they were able to do was to try, by brute force, threats and restrictions, to force the black community off the streets for carnival in 1976. But they also offered the 'carrot' before they came with the 'stick.' Their carrot was that money could be made out of the carnival. The council agreed.

Carter (1986:221) succinctly describes the situation:

The 1976 carnival was a watershed in relations between black people and the police, marking the transition from a period of when 'cultural diversity' and harmonious race relations were still the stated goal of public policy to a period in which the brute fact of institutional racism could no longer be disguised.

Still another suggests: 
Carnivalists regarded the 1976 carnival riots as a protest on different levels. First of all the protest was directed against over policing at that carnival. Secondly and more indirectly the protest was directed against the socio-economic situation. . The riots were a general protest against white authority, similar to the carnival riots in Trinidad in the 1800s, when the British colonists threatened to ban carnival there (Hulls 1997:100).

Others also concur:

In 1976, however, the festivities were interrupted on the last day. Young blacks harassed by a police presence numbering 1,600 defended themselves against arbitrary police arrests. The large police presence was 'justified' by shady allegations of mass out-breaks of petty crime by young blacks in the crowds. But, this was no excuse for the massive police presence. The young blacks, people with good memories, knew that police were there for the express purpose of terrorizing them. Mass arrests of young blacks is so commonplace, the police so hated, that the police force of the entire country had only a couple of dozen black police officers (www.libcom.org/ history/1976-the-notting-hill-carnival-riots).

Additionally:

The Notting Hill riots were a collective reply by the young black community to years of police repression. They were not race riots but anti-police riots by (mostly) unemployed, low paid, young blacks, the people at the bottom of the economic and social scrapheap (www.libcom.org/1976-the-notting-hill-carnival-riots).

The 1970s and 1980s were clearly characterized by conflicts between various groups including the police and the black population, as well as between whites and black ethnicities (Jackson 1987). As Jackson (1987:216) notes:

Carnival can be said to have assumed a more clearly Trinidadian identity in the early 1970 s as the polarization between blacks and whites increased in a period of rising unemployment and intensifying social conflict. Carnival began to be used as an organizing mechanism for protest and opposition. 
So too, Melville (2002), argues that the carnivals of the later 1970s and 1980s can be described as a period of tension with frequent conflicts. As Melville (2002:34) states:

The carnivals of 1975 and 1976, in particular, were marked by confrontation between black youth and the police. Tensions had always been there. With some justification, black Londoners regarded the British police as forces of arbitrary oppression. Throughout the 1970s, the use of heavy-handed tactics such as the suspicious persons laws meant that there was scarcely a single black person in London who had not been stopped and searched by police, many numerous times. This, combined with frankly idiotic police containment tactics, made confrontation 'inevitable'.

During the 1980s, black residents experienced racism and other forms of social inequality (Cohen 1993). They dealt with such treatment by organizing opposition; that is, they organized marches and increased participation in the electoral process in local politics (Cohen 1993). While carnival continued to be an intense event, the period of 1980 to 1986 also represented the strengthening of cultural homogenization. Cultural homogenization, in the case of the Notting Hill Carnival, refers to a consolidation of cultural practices. According to Cohen (1993:45) "the period of 1980 to 1986 saw the integration of the mobile bands and the stationary sound systems, and the rise of the stall holders as effective agents of cultural homogenization."

In addition to race, issues of class and status further exacerbated the conflict relationship. For instance Smith (1984:371) points out:

The dramatized assertions of ethnicity need not be a conscious attempt to demand or secure political and economic rights. Indeed, for the general public, it is often merely a pragmatic means of reducing the perceived risks of daily life. However, there is a struggle for power endemic to all forms of human relationships, and within the inner-city, much of this struggle takes place over the symbolic rewards of prestige or status - for there is little else to win.

Contributing to the conflict was the carnival of 1989, deemed by many the "police carnival" (Hulls 1997). According to one participant, the 1989 Carnival was different from many carnivals in the past (Oral History Interview 2001). As this individual observed:

The police started to actually interfere with the masquerade bands. They would try and stop people leaving the 
bands and going to the toilet. They would throw barriers across the road and stop bands moving forwards and backwards, threatening people with arrest and all kinds of things (Oral History Interview 2001).

Finally, additional evidence points to a conflict relationship during the 1980s. In this regard La Rose (1990:9) notes:

The British government cannot destroy carnival. It is an internationally known event. But it can be completely controlled and licensed. . .Carnival 1989 was under total police control. The police want carnival to start at 11:00 A.M. and finish at 7:00 P.M. No bands will be allowed in after 11:00 A.M. We want the carnival festival to end at 11:00 P.M. like a pub or local council hall or any other place of public entertainment. . The police must not treat carnival as a public order problem. It's a cultural festival.

In sum a wide array of data reveals that during this time period the police viewed the carnival as a public safety problem which directly contributed to the conflict relationship. According to the Notting Hill Organizational Review (1988:1, 2):

For the police, carnival is a public safety headache planned to meet the conflicting demands of the 'hands off' approach to avoid provocation and the 'hands on' approach to control crime. This is against a background where police/black relations have never been good, and, at times, are openly hostile. . .Underlying these tensions is both real and perceived racism or, at least, misunderstanding.

Further, according to the review, "the carnival has remained predominantly a minority event which to date, despite its huge attraction of tourists and nationals alike, continues to face opposition from politicians and residents" (Notting Hill Organizational Review 1988:5).

\section{TIME PERIOD \#4}

The social relationship between the black population and dominant whites from 1990 to the present can best be described as conflict accompanied by an underlying social dynamic involving exchange. Hence, confrontation and conflict continue to take place, yet the carnival is also viewed as an important ritual event.

The carnival takes place over the last Sunday and Monday in August, and parades, processions and music at- 
tract a throng of visitors and celebrants. It is no surprise that during its existence the celebrations have been the cause both of community cohesion and community disharmony (www.cengage.co.uk/shone3/students/cases/ nottinghill.pdf).

Moreover, according to Gutzmore (1993), confrontation and violence have taken place at carnival in relation to several aspects of the festival such as cultural venues and practices, among others. As he argues, "the Notting Hill Carnival is perhaps the most spectacular of those cultural events that actually led to violent conf rontation between the black communities and the state (Gutzmore 1993:208)."

Further, according to one interviewee, racism continues to represent a serious issue in Britain:

The sense of the black community, black people and blackness and so on is not, as it is today, a black for describing Caribbeans or even Africans - it characterizes non-whites who are feeling that they are having a bad, difficult time in racist Britain, and have to ban together to resist injustice, but also to engage with the white community, yes, to transform it, to grab it in a way that's better. . .To enjoy themselves or to educate them about oppressions of people in U.K., that kind of stuff (Oral History Interview 2003).

And issues of crime have played a role in the conflict relationships between the black and white populations.

The way in which the carnival is currently perceived has been shaped more by crime figures than its positive social and economic contribution to London's economy and cultural dynamism. . .The history of the Notting Hill carnival and the reason for its existence are firmly rooted in the ideals of freedom, unity and community empowerment. And yet so much of the language and debate about the carnival has been centered on how the event should be "contained" (Notting Hill Carnival: A Strategic Review, 2004). However, the spirit of carnival as a very special collective event remains strong. Carnival will never die. The question is: what kind of carnival will we have in Britain? For the past 15 years there has been an unrelenting struggle by the British state to stop carnival being a day when the people have the freedom of the streets for masquerade, artistic celebration and enjoyment. In recent times the Home Office and the Met- 
ropolitan Police have eased up a little on attempts to ban carnival altogether (Association for a People's Carnival 1991:1).

So too another interviewee observes:

Carnival can be a tremendous unifier, a tremendous educator, can be used in so many positive and constructive ways, but I don't think, because again the sort of politics or personalities that sometimes are involved, that is allowed to happen (Oral History Interview 2003).

Thus, while conflict continues to remain a part of the social relationship, carnival has continued despite such discord. As Melville (2002:1) suggests, "yet all in London's multicultural garden is no celebration of a pre-existing harmony, but an attempt to found a multicultural community, sometimes in the face of extreme adversity." Or as another participant observed, "carnival has a very bright future and it's too late to stop it now because people will not stop. It's too important to the Caribbean people and to London now and to everybody to stop it" (Oral History Interview 2001).

And some contend that the attitude among the police has improved as they have become more enlightened. As a result they now work well with the community (Oral History Interview 2001). Finally, as one participant stated:

You can't kill the carnival you know. History has taught us you can't stop the carnival, once you let it out there's no turning back. . .That spirit permeates everybody. . .I think the future of Notting Hill Carnival is here to stay, what else would you put in its place? London's biggest tourist attraction, rooted in the culture. But conflicts must be lessened and it must be accepted as a national cultural experience. Carnival started off with the need to liberate the slaves but it has developed for everybody to take part in it, whole society involved. Class structures are broken down, everybody is united (Oral History Interview 2001).

Thus, we find that various groups now benefit from the staging of this collective ritual event ranging from the strengthening of collective ties among the varied participants and its historic importance to Caribbean people to the economic gains brought to the wider community due to the large numbers of tourists and locals who attend. 


\section{DISCUSSION}

Willer (1999) argues that elementary theory is based on the basic assumption that social relations are found in every society and these relations can be represented by distinct typologies. As previously stated, we suggest that the social relationships of coercion, conflict and exchange are found in the four time periods presented dealing with the enactment of the special collective ritual event(s) of the Trinidad Carnival and later the Notting Hill Carnival in London.

According to Willer (1999:27) coercion represents a relation in which "one actor has a negative sanction and the other has a positive sanction. The actor with the negative is the coercer and the actor with the positive is the coercee." If the coercer threatens coercees with a negative sanction and the coercees provide a positive response, the coercer will not send the negative sanction. We contend that during the first part of time period \#1 (prior to the 1830s in Trinidad) the social relationship was a coercive one as slaves were prohibited from participating in the event. Conflict did not appear, therefore, because the slaves provided the desired positive response by not attempting to participate. Moreover, the coercive relationship served as a means for preserving the social order. Hence, by excluding certain individuals from participating in the event the social hierarchy was clearly defined and reinforced.

During the second stage of time period \#1, the social relationship is best described as one of conflict. The conflict or confrontational relationship involves a situation in which both actors threaten to and/or do transmit negative sanctions. Agreements occur when no sanctions are carried forth. During the second phase of time period \#1, carnival participants (i.e., newly freed slaves) began to openly voice numerous concerns about social problems including political inequities. This was viewed by the elite as a negative sanction directed toward them. As a result, those in power transmitted negative sanctions toward the freed slaves in the attempt to prohibit certain behaviors that were an integral part of the carnival experience. Hence, the relationship was one of conflict as the carnival continued despite opposition and contention. Each side produced negative responses to one another creating a conflict relationship as outlined in elementary relations theory.

In time period \#2 (1965-1974) the social relationship between the minority and dominant groups in the collective ritual event of the carnival was characterized by exchange. According to Willer (1999), exchange relationships develop when both actors benefit, i.e., are rewarded. During the second time period, carnival provided an emotional release for participants; that is, it allowed the masses to have a few days per year to protest against poor social conditions while engaging in an enjoyable collective experience (Jackson 1987). Thus, the carnival was an event 
that allowed people to express their frustrations over a two day period while the dominant group maintained its power. While nothing tangible was exchanged between the groups, each side clearly benefited. Stated another way, certain social arrangements were upheld or preserved. Hence, the festival provided an emotional release for participants, providing an internal gain to this group. The relationship also served to uphold the social and political order of the larger community, i.e., maintained the status quo. More specifically, the white elite maintained control. This may help to explain why the Notting Hill Carnival was left alone for the first few years. As Gutzmore (1993:215) observes:

The police participated, incidentally, in the Notting Hill Carnival for all of those years, and they got enormous propaganda out of its reassurance to the black community that they were nice people, although we know differently; reassurance to the great white public that they were nice people - and we know differently. Specifically, the question has got to be asked, why was it that the carnival didn't look threatening for its first eight years? Let's say it started in 1966 . The reason is that it was organized in the early days by white people.

Time period number three is marked by a very salient conflict relationship. During the 1970s, carnival participants protested against the poor socioeconomic situation that young blacks had to cope with in Britain (Hulls 1997). Thus, carnival was a mechanism for protest (Jackson 1987). Further, "carnival can be said to have assumed a more clearly Trinidadian identity in the early 1970 s as the polarization between blacks and whites increased in a period of rising unemployment and intensifying social conflict" (Jackson 1987:216). As a result the dominant group began to transmit negative sanctions toward carnival participants and the black community. For instance the 1976 carnival riot is considered to be a watershed event in the history of conflict between the black community and the police. Hence, carnival "entered the domain of threatening culture, because it was then mass culture, active mass culture and it therefore had to be suppressed or controlled" (Gutzmore 1993:216).

The 1980s also represented a time of conflict. According to Cohen (1993) members of the Notting Hill community's black population fought against racism through organized marches and increased political participation. However, measures were taken by those in power to contain and control the celebration. As a result the threat of violence remained present.

The final time period (\#4) may be described as a time of conflict along with a relationship of exchange. Thus, while carnival was still viewed by some as threatening it continued to be a large and important 
part of London's culture. According to the Association for a People's Carnival (1991:1) "for the past fifteen years, there has been an unrelenting struggle by the British state to stop carnival being a day when the people have the freedom of the streets for masquerade, artistic celebration and en joyment." However, in recent years, there has been less of an effort to ban carnival. While conflict continues, so has carnival (Melville 2002). More specifically, the exchange relationship is evident as the ritualized festival increasingly represents a cultural event and an attempt to bring about a multicultural community. Although conflict continues to exist, the carnival is an important event to Caribbean people and many others. In return, it attracts tourists and that is beneficial to London (Oral History Interview 2001).

\section{CONCLUSION}

The Notting Hill Carnival is a special collective ritual event that has played a crucial role in three quite different structural arrangements since its inception in London and previously in Trinidad. Utilizing elementary relations theory (and structural ritualization theory) we analyzed the various social relationships the Notting Hill festival has been a part of. Further, employing content analysis we found that these three types of social relationships occur to varying degrees in four distinct time periods.

First, the social relationship of coercion is present prior to the abolition of slavery in Trinidad followed by a conflictual relationship which dominated during the period following emancipation. The major structural relationship during the second time period which marked the beginning of the Notting Hill Carnival in London involved a process of social exchange. Finally, the last two time periods involve conflict relationships with social exchange also playing an important role in the final period.

Rituals take varied forms, can have very different consequences, and can be involved in very different social processes. Quite of ten they are important social events that unite people. However, a ritual event is not only an integrative endeavor; it can also be a part of different types of group dynamics and relational arrangements. Here we find quite vivid evidence of how collective ritual events have been used by agents in quite varied ways resulting in very different structural relationships.

This study and its findings are relevant for several reasons and have a number of implications. To begin with while other studies have been conducted of the Notting Hill Carnival (some of which we have drawn upon) they tend to focus on the role of collective memory, the social construction of the carnival and sense of community among participants, or transformations in the event in recent years. Our approach differs from these other important studies in that we focus on how this ritual 
event is a part of and impacted by the wider web of structural relations within which the carnival occurs (the larger metropolitan community, other groups in contact with the event and its participants, and so on). And we take a broad historical approach directing attention to the last half century and also the origins of the carnival in the 19th century.

In doing so the current study conceptualizes carnival as a special collective ritual event and emphasizes how a social ritual such as this can endure over significant periods of time, may spread to other cultures, and can change in terms of its structural relations and dynamics. Contrary to the not uncommon assumption in the social sciences that rituals are social events that are fixed and static we argue that rituals can be dynamic and possess the potential for change.

Furthermore this investigation stresses how ritual events such as the Notting Hill Carnival can be strategically used in very different types of relationships. While some research in recent years has demonstrated how ritual practices can be used in strategic ways and may be intimately linked to the use of power and differences in power among groups (e.g., Kertzer 1988; Lane 1981; Petrone 2000; Edwards and Knottnerus 2007, 2010; Knottnerus and LoConto 2003; Knottnerus, Van Delinder and Edwards 2011) this issue deserves much more extensive study. Elementary relations theory provides a useful conceptual framework for distinguishing some of the different ways phenomena such as rituals can play a crucial role in social dynamics and the structuring of society. Research of this sort helps to counter the implicit if not explicit assumption made by various social scientists that the main role rituals play in social life is to contribute to the preservation of existing social arrangements, i.e., rituals essentially involve traditions and customs that are fundamentally conservative in nature.

Preliminary evidence from this study along with field observations (by the first author) also suggests that carnival has become a quite prominent event in London and elsewhere. From the perspective of structural ritualization theory this festival could be considered a highly ranked RSP. According to the theory various factors (i.e., salience, homologousness, repetitiveness, and resources) influence the overall rank or strength of a RSP. This is an issue that could be formally investigated in order to determine whether and to what degree this is the case. Such research would also include an analysis of the various symbolic themes expressed through this potentially highly ranked ritual. This analysis could then be linked to the findings of the present study to provide a richer and more comprehensive understanding of how the ritual dynamics of the current carnival are impacting structural relationships and arrangements (e.g., are symbolic themes stressing racial/ethnic group interests and pride or multicultural identity and cooperation evident 
which might in turn impact the nature of the relations between ritual participants and the police, political decision-makers, or the media). Finally, attention could be given to the organizational base of the carnival and how this facilitates the production of this collective ritual event.

In closing, the Notting Hill Carnival provides compelling evidence of how rituals can have multiple consequences and can be used in many ways to construct different social relations. Hopefully the present study will provide the foundation for subsequent studies of the ritual dynamics of this particular event as it continues to evolve. More generally research of this type could be directed to other similar ritual events, i.e., carnivals and festivals, throughout the world. In doing so we should gain an enhanced appreciation for how these kinds of social rituals can play an integral role in the structuring of group relations and how individuals and groups are affected in different ways by their enactment.

\section{REFERENCES}

A Large-Scale Community Event and the Notting Hill Carnival, London, England. www.cengage.co.uk/shone3/students/cases/nottinghill.pdf

Association for a People's Carnival. 1991. Newsletter.

Babbie, Earl. 2004. The Practice of Social Research. Belmont, CA: Thomson/Wadsworth.

Bankston, C.L. and J. Henry. 2000. "Spectacles of Ethnicity: Festivals and the Commodification of Ethnic Culture Among Louisiana Cajuns." Sociological Spectrum 20:377-403.

Bereton, Bridget. 1985. Social Life in the Caribbean, 1838-1938. Oxford, United Kingdom: Heineman Publishers.

Bhandari, Roshan Bhakta, Norio Okada, and J. David Knottnerus. 2011. "Urban Ritual Events and Coping with Disaster Risk: A Case Study of Lalitpur, Nepal." Journal of Applied Social Science 5:13-32.

Carter, Trevor. 1986. Shattering Illusions: West Indians in British Politics. London, United Kingdom: Lawrence and Wishart.

Carver, Gavin. 2000. "The Effervescent Carnival: Performance, Context, and Mediation at Notting Hill." New Theatre Quarterly 16:34-49.

Cohen, Abner. 1982. "A Polyethnic London Carnival as a Contested Cultural Performance." Man

1983. "Drama and Politics in the Development of a London Carnival." Pp. 101-126 in Political Anthropology Vol. 2: Culture and Political Change, edited by Myron J. Aronoff. New Brunswick, NJ: Transaction Inc. 
1993. Masquerade Politics: Explorations in the Structure of Urban Cultural Movements. Berkeley, CA: University of Ca. Press.

Connerton, Paul. 1989. How Societies Remember. Cambridge, United Kingdom: Cambridge University Press.

Edwards, Jennifer and J. David Knottnerus. 2007. "The Orange Order:

Strategic Ritualization and Its Organizational Antecedents." International Journal of Contemporary Sociology 44:179-199.

. 2010. "The Orange Order: Parades, Other Rituals, and Their Outcomes." Sociological Focus 43:1-23.

Guan, Jian and J. David Knottnerus. 1999. "A Structural Ritualization Analysis of the Process of Acculturation and Marginalization of Chinese Americans." Humboldt Journal of Social Relations 25:4395.

. 2006. "Chinatown Under Siege: Community Protest and Structural Ritualization Theory." Humboldt Journal of Social Relations 30:5-52.

Gutzmore, Cecil. 1993. "Carnival, the State, and the Black Masses in the United Kingdom."Pp. 207-230 in Inside Babylon Caribbean Diaspora in Britain, edited by Winston James and Clive Harris. London, United Kingdom:Verso.

Huls, Martina. 1997. The Notting Hill Carnival. Universitat Osnabruck, Master's Thesis.

Jackson, P. 1987. "Street Life: The Politics of Carnival." Environment and Planning 6:213-227.

Kensington and Chelsea Community History Group. 2001. Oral History Interviews.

. 2003. Oral History Interviews.

Kertzer, David I. 1988. Ritual, Politics, and Power. New Haven, CT: Yale University Press.

Knottnerus, J. David. 1997. "The Theory of Structural Ritualization.” Pp. 257-279 in Advances in Group Processes, Volume 14, edited by Barry Markovsky, Michael J. Lovaglia and Lisa Troyer. Greenwich, CT: JAI Press.

. 1999. "Status Structures and Ritualized Relations in the Slave Plantation System. Pp. 137-147 in Plantation Society and Race Relations: The Origins of Inequality, edited by Thomas J. Durant, Jr. and J. David Knottnerus. Westport, CT: Praeger. . 2002. "Agency, Structure and Deritualization: A Comparative Investigation of Extreme Disruptions of Social Order." Pp. 85-106 in 
Structure, Culture and History: Recent Issues in Social Theory, edited by Sing C. Chew and J. David Knottnerus. Lanham, MD: Rowman \& Littlefield.

. 2005. "The Need for Theory and the Value of Cooperation: Disruption and Deritualization." (Presidential Address, Mid-South Sociological Association, Baton Rouge, 2003). Sociological Spectrum 25:5-19.

2009. "Structural Ritualization Theory: Application and Change" Pp. 70-84 in Bureaucratic Culture and Escalating World Problems: Advancing the Sociological Imagination, edited by J. David Knottnerus and Bernard Phillips. Boulder, CO: Paradigm Publishers.

2010. "Collective Events, Rituals, and Emotions." Pp. 39-61 in Advances in Group Processes, Volume 27, edited by Shane R. Thye and.Edward J. Lawler. Bingley, United Kingdom: Emerald Group Publishing Limited.

2011. Ritual as a Missing Link: Sociology, Structural Ritualization Theory and Research. Boulder, CO: Paradigm Publishers.

Knottnerus, J. David and Phyllis E. Berry. 2002. "Spartan Society: Structural Ritualization in an Ancient Social System." Humboldt Journal of Social Relations 27:1-42.

Knottnerus, J. David and David G. LoConto. 2003. "Strategic Ritualization and Ethnicity: A Typology and Analysis of Ritual Enactments in an Italian American Community." Sociological Spectrum 23:425461.

Knottnerus, J. David, Jason S. Ulsperger, Summer Cummins, and Elaina Osteen. 2006. "Exposing Enron: Media Representations of Ritualized Deviance in Corporate Culture." Crime, Media, Culture: An International Journal 2:177-195.

Knottnerus, J. David and Frédérique Van de Poel-Knottnerus. 1999. The Social Worlds of Male and Female Children in the Nineteenth Century French Educational System: Youth, Rituals and Elites. Lewiston, NY: Edwin Mellen Press.

Knottnerus, J. David, Jean Van Delinder, and Jennifer Edwards. 2011. "Rituals and Power: A Cross-Cultural Case Study of Nazi Germany, the Orange Order, and Native Americans." Pp. 73-105 in Ritual as a Missing Link in Sociology: Structural Ritualization Theory and Research, J. David Knottnerus. Boulder, CO: Paradigm Publishers. 
La Rose, Michael. 1990. Mas in Notting Hill: Documents in the Struggle for a Representative and Democratic Carnival. London, United Kingdom: New Beacon Books.

Lane, Christel. 1981. The Rites of Rulers: Ritual in Industrial SocietyThe Soviet Case. Cambridge: Cambridge University Press.

Lin, Xiaohua, Jian Guan, and J. David Knottnerus. 2011. "Organizational and Leadership Practice of Micro Ethnic Entrepreneurship in Multicultural Context: A Structural Reproduction Analysis." International Journal of Business Anthropology 2:48-65.

Melville, Casper. 2002. "A Carnival History.” www.openDemocracy.net Minton, Carol and J. David Knottnerus. 2008. "Ritualized Duties: The Social Construction of Gender Inequality in Malawi." International Review of Modern Sociology 34:181-210.

Mitra, Aditi and J. David Knottnerus. 2004. "Royal Women in Ancient India: The Ritualization of Inequality in a Patriarchal Social Order." International Journal of Contemporary Sociology 41:215-231.

. 2008. "Sacrificing Women: A Study of Ritualized Practices Among Women Volunteers in India." Voluntas: International Journal of Voluntary and Nonprofit Organizations 19:242-267.

Notting Hill Carnival: A Strategic Review. 2004. Greater London Authority.

Notting Hill Carnival History. www.thecarnival.tv/info/history1.htm

Notting Hill Organizational Review. 1988.

Petrone, Karen. 2000. Life Has Become More Joyous, Comrades: Celebrations in the Time of Stalin. Bloomington: Indiana University Press.

Sarabia, Daniel and J. David Knottnerus. 2009. "Ecological Stress and Deritualization in East Asia: Ritual Practices during Dark Age Phases." International Journal of Sociology and Anthropology (Open Access Online Journal): 1(1):012-025, May. www.academicjournals.org/IJSA/contents/2009cont/May.htm

Sell, Jane, J. David Knottnerus, Christopher Ellison, and Heather Mundt. 2000. "Reproducing Social

Structure in Task Groups: The Role of Structural Ritualization," Social Forces 79:453-475.

Smith, Susan J. 1984. "Negotiating Ethnicity in an Uncertain Environment." Ethnic and Racial Studies 7:360-373. 
Thornburg, P. Alex, J. David Knottnerus, and Gary R. Webb. 2007. "Disaster and Deritualization: A Re-interpretation of Findings from Early Disaster Research.” The Social Science Journal 44:161-166. . 2008. "Ritual and Disruption: Insights from Early Disaster Research." International Journal of Sociological Research 1:91-109.

Ulsperger, Jason S. and J. David Knottnerus. 2007. "Long-term Care Workers and Bureaucracy: The Occupational Ritualization of Maltreatment in Nursing Homes and Recommended Policies." Journal of Applied Social Science 1:52-70.

. 2008. "The Social Dynamics of Elder Care: Rituals of Bureaucracy and Physical Neglect in Nursing Homes." Sociological Spectrum 28:357-388 (2008 Sociological Spectrum Article of the Year Award).

. 2009 a. "Illusions of Affection: Bureaucracy and Emotional Neglect in Nursing Homes." Humanity and Society 33:238-259.

. 2009 b. "Institutionalized Elder Abuse: Bureaucratic Ritualization and Transformation of Physical Neglect in Nursing Homes" Pp. 134-155 in Bureaucratic Culture and Escalating World Problems: Advancing the Sociological Imagination, edited by J. David Knottnerus and Bernard Phillips. Boulder, CO: Paradigm Publishers.

. 2011. Elder Care Catastrophe: Rituals of Abuse in Nursing Homes - and What You Can Do About It. Boulder, CO: Paradigm Publishers.

Van de Poel-Knottnerus, Frédérique and J. David Knottnerus. 2002. Literary Narratives on the Nineteenth and Early Twentieth-Century French Elite Educational System: Rituals and Total Institutions. Lewiston, NY: Edwin Mellen Press.

. 2011. "Disruption and Deritualization: Concentration Camp Internment and the Breakdown of Social Order" Pp. 107-131 in Ritual as a Missing Link: Sociology, Structural Ritualization Theory and Research. Boulder, CO: Paradigm Publishers.

Varner, Monica K. and J. David Knottnerus. 2002. "Civility, Rituals and Exclusion: The Emergence of American Golf During the Late Nineteenth and Early Twentieth Centuries." Sociological Inquiry 72:426441.

2010. American Golf and the Development of Civility: Rituals of Etiquette in the World of Golf. Koln, Germany: LAP Lambert Academic Publishing.

Waskito, Agung. 2010. www.listentotheworld.net 
Willer, David. 1999. "Actors in Relations." Pp. 23-48 in Network Exchange Theory, edited by David Willer. New York, NY: Praeger.

Willer, David and Bo Anderson, eds. 1981. Networks, Exchange and Coercion. New York: Elsevier/Greenwood.

Willer, David and Barry Markovsky. 1993. "The Theory of Elementary Relations: Its Development and Research Program." Pp. 323-363 in Joseph Berger and Morris Zelditch, Jr., eds., Theoretical Research Programs: Studies in Theory Growth. Stanford, CA: Stanford University Press.

1976: The Notting Hill Carnival Riots. 2006. www.libcom.org/history/ 1976-the-notting-hill-carnival-riots 